\title{
Comparative Study of Chinese and American Media Reports on the COVID-19 and Expressions of Social Responsibility: A Critical Discourse Analysis
}

\author{
Yanni Zhang ${ }^{1} \cdot$ Naveed Akhtar $^{3} \cdot$ Qamar Farooq $^{2,3} \cdot$ Yiwei Yuan $^{4} \cdot$ Irfan Ullah Khan $^{5}$
}

Accepted: 4 August 2021 / Published online: 9 September 2021

(C) The Author(s), under exclusive licence to Springer Science+Business Media, LLC, part of Springer Nature 2021

\begin{abstract}
Critical discourse analysis aims to explore the dialectical relationship between discourse and ideology. Based on psycholinguistic research, this paper analyzes the Chinese and American media's news reports and comments on the COVID-19. It aims to expose the hidden psychological messages and ideologies behind the words. The corpus in this paper is mainly from the official media of China Daily and Time from December 2019 to January 2021 in China and the United States. This paper uses Wang Zhenhua's Appraisal Theory and Halliday's Systemic Functional Grammar as tools to make a comparative analysis of the corpus. At the textual level, languages are classified and lexical choices are analyzed followed by the analysis of the reporter's ideology after reviewing the motivation of the reporters of two countries. On the level of social responsibility expression and discourse, the paper analyzes the news reports, which are characterized by the combination of the reporter's views on the news. In the aspect of social practice, the social and cultural factors and background of news reports are analyzed. China calls for strengthening cooperation and exchanges with other countries to jointly fight the epidemic. The Chinese government has actively shared its experience and made corresponding contributions to international economic recovery. However, the US government shirks its responsibility by claiming that the effective implementation of Chinese methods and experience in China does not mean that it can achieve corresponding results in Europe and the US. At the same time, the United States provides medical supplies to other countries. This study hopes to help awaken readers' critical thinking and increase their awareness of the anti-control of mass discourse. At the same time, it is hoped that readers can view the epidemic from a more scientific perspective, understand the facts and reject the unwarranted panic. It will also help reshape Chinese and American discourse.
\end{abstract}

Keywords COVID-19 · Critical discourse analysis · Appraisal theory · News reports · Ideology $\cdot$ Social responsibility

Qamar Farooq

f4farooq@outlook.com

Extended author information available on the last page of the article 


\section{Introduction}

\section{Background}

Since the end of 2019, the outbreak of COVID-19 has attracted the attention of scholars around the world. At the same time, it has also aroused the attention of the news media. The international media actively reported the research results of national health organizations and the World Health Organization (WHO), such as the source, symptoms, mode of transmission, and harm of the virus. The perception about COVID-19 pandemic has also been globally tweeted (Essam \& Abdo, 2020). Today, the outbreak has become a public health event, so the dynamic surroundings are relevant to everyone's safety. In other words, the news media, especially the relevant official reports, are particularly important, because they are the real-time and reliable window for people to understand the dynamics of the epidemic. Therefore, the psycholinguistic discourse of COVID-19 news brings a challenge for discourse analysis across the Regions.

News reports are the reports of recent facts and the source of news is to focus on the event itself (Freudenburg et al., 1996), so the news reports require to be objective and true. However, to adequately communicate a social event, there is a dire need to express social responsibility in reported news which often starts from its subjective perspective. Different aspects of observation, opinions, and words have a psychological impact on the reader's understanding of the truth. However, since the outbreak of COVID-19, the political relationship between China and the United States has been in crisis and the war of public opinion and media between China and the United States is in progress. World Health Organization named the virus COVID-19 at a press conference in Geneva and said the virus is without borders. However, the United States, especially former president Trump and other individuals and groups have advocated COVID-19 as the "Chinese virus" in their statements, which did not comply with the World Health Organization's naming regulations.

Critical discourse analysis is a method of comparative discourse analysis. Based on the understanding of discourse as a kind of social practice, it aims to explore the dialectical relationship between discourse and ideology and further reveals the ideology hidden behind language, thus providing theories and methods for the study of news discourse. It helps people to have a more rational and objective interpretation of news reports and assists them to understand the truth. Through literature research, this paper uses critical discourse to analyze reports related to the COVID-19 in official media, China Daily and Time, in China and the United States respectively. This paper aims to improve readers' cognition of news language and help readers to interpret news reports rationally and accurately.

\section{Methodology}

Through literature research, this paper studies the relevant news reports about COVID-19 in China and the United States since December 2019. Through the analysis of news discourse, the hidden information and potential ideology in the American media is revealed which examines the image American media portrayed in China and vice versa due to the psycholinguistic issue. This paper is based on Wang Zhenhua's evaluation theory and Halliday's Systemic-Functional Grammar. In order to make the analysis more credible and convincing, the content of the report is selected from China Daily and Time, which are mainstream media with huge influence in both China and the United States. 


\section{Significance}

After the outbreak of COVID-19, the Chinese government paid great importance to it and took resolute and forceful measures, including restricting traffic, closing schools, strict quarantine, compulsory isolation, and even city closure. The goal was to prevent millions of people from becoming infected with COVID-19 and to protect the safety and health of the general public. China's scientific and effective prevention and control measures have checked the expansion of the COVID-19 and China has maintained close communication and high cooperation with WHO and the international community. Various measures have been effectively taken to prevent the spread of the COVID-19, demonstrating China's demeanor and sense of responsibility as a major socially responsible country. China's achievements in dealing with the COVID-19 have attracted the attention of all countries in the world. Western media also continue to report about COVID-19. However, due to different positions and tendencies, Western media, especially American media, hold a misunderstanding and negative attitude towards the Chinese government and accuse the Chinese government. The United States tried to associate the COVID-19 with China, slanting China and calling it "Chinese virus" and "Wuhan virus". In addition, the United States denigrates China for using the coronavirus crisis to position itself as a global leader, while in fact infinitely expanding the impact of the virus on the world. The United States labeled the quarantine under the COVID-19 epidemic as a "violation of human rights" and used discriminatory reports to attack the Communist Party of China and the Chinese government. Therefore, the Critical Discourse Analysis (CDA) of international media reports about COVID-19 for psycholinguistic harmony is needful.

The findings of this paper will be of great significance in the following aspects: Due to the rapid development of the Internet, people's access to information becomes more and more convenient. At the same time, the interaction between discourse and ideology becomes more complex. Therefore, the importance of critical reading for psycholinguistic harmony is becoming increasingly prominent. Using the CDA method to reveal the language ideology contained in media discourse can find the relationship between language, power, and ideology. Thus, it can improve people's critical discourse awareness and critical reading ability in the context of COVID-19. Currently, the epidemic is still going on, thus this paper can help people interpret news reports more rationally and objectively. When the truth is known, it will prevent unwarranted panic and help reshape China's discourse.

\section{Theoretical Development}

\section{Definition of Critical Discourse Analysis}

Discourse is an essential element in any communication process no matter it is business research, marketing research, management research, or linguistic research; it plays a vital role in every field. CDA was first proposed and used by the British linguist Fowler in his book Language and Control. CDA regards language as a multi-functional system, so Halliday's Systemic Functional Linguistics is its main theoretical basis and method source. Halliday believes that language has three pure functions: conceptual function, interpersonal function, and textual function (Wodak \& Meyer, 2015). These functions can raise or eradicate psycholinguist issues across cultures and countries. Systemic Functional Grammar provides insight into the meaning and validity of a text. Systemic Functional Linguistics 
(Eggins, 2004) advocates that discourse analysis not only analyzes language and language use but also evaluates discourse concerning culture, politics, and ideology.

CDA is a new way of discourse analysis based on linguistic evaluation in terms of psychological understanding. It takes linguistics as the main body and language analysis as the means to reveal the complex relationship among language, power, and ideology. Halliday's Systemic Functional Grammar (Halliday \& Matthiessen, 2013) is the main theoretical basis and methodological source of CDA. According to him, the nature of language is closely related to what we need it to do and what it is supposed to do. He also proposed that language must meet the needs of the user in three aspects: expressing the experience of the subjective and objective world, reflecting the relations between people, choosing words and constructing sentences, and organizing discourse, which is known as the three "pure functions" of language: "conceptual" function, "interpersonal" function and "discourse" function. Conceptual function refers to the expression of human experiences in the real world (including the inner world) by language. Classification and lexical selection are the determinants of conceptual function. Interpersonal function refers to the function of language to express the speaker's attitude, motivation, and judgment of things highlighting the psychic state of the speaker and the audience. Textual function refers to the function of language to form any spoken or written discourse into a coherent and unified discourse. Among them, the choice of theme and rhyme can highlight some parts of the text.

\section{CDA's Role in Researching News Reports}

News discourse is one of the most important objects of critical discourse analysis which can positively or negatively affect businesses, the economy, management, societies, and international relations. CDA focuses on practice. By combining language with society, it reveals the relationship between ideology and rights behind the language (Romaine, 2000). On the one hand, news claims to report reality. On the other hand, it conveys social meaning and ideology to the public through language, which embodies the control and dissemination of rights and ideologies. Because news organizations have more access to information and more rights than the public, they will dominate in terms of content, words, and style. Therefore, critical linguistics applies to news analysis precisely because critical linguistics can use language analysis to reveal misdirection and discrimination in various modes of public discourse. It provides a critical analysis of newspapers, political propaganda, official literature, regulations, formal conversations, interviews, and soon. More generally speaking, CDA is not so much a method of discourse analysis as an attitude towards problems reflecting psycholinguistic analysis. Viewing the problem from a critical point of view can help the reader not to accept the convention easily and make a deep linguistic analysis of the text.

The principle of news reporting is to present the truth of an event to readers objectively and truthfully. However, as a social practice, sometimes journalists will be driven and influenced by their values, positions, tendencies, thinking levels, and various interests. This is because journalists soften or deal with the fact syntactically or rhetorically. It consciously highlights, accentuates, and plays up certain facts. At the same time, the reporter will guide the public opinion to pay attention to some focal points or adjust the emotion of the audience according to his intention, so it is the interference of the social construction of reality.

In the context of the information age, mass media carries the information transmission of the whole society and is an indispensable part of human life, while the main analysis objects of critical discourse analysis are the legalized and ritualized mass discourse. Western societies, 
especially the United States, have always claimed that their society is democratic and liberal, and their news reports are always objective and impartial. However, the fact is far from this, because practically, no piece of news can reflect the views of all people or represent the interests of all people. What events are reported as news does not depend on the event itself but on the lexical choices of the reporter as to how do they target the audience psychologically. In the process of reporting, it is up to the reporter to choose which material to focus on and which people's opinions to cite. Thus, the news report is not an objective and impartial report of the facts as claimed, but also represents the special interests of a person or group. By analyzing the news discourse about COVID-19 through CDA the meaning of the discourse can be understood. It can help readers learn to understand the content of the text rationally and prevent the interference of external factors.

\section{Definition of Appraisal Theory}

Martin and White (2003) innovated Halliday's linguistic school and constructed the structure of the discourse evaluation system. Martin defined evaluation theory as "Evaluation theory is about evaluation, namely the various attitudes negotiated in the text, the intensity of the emotions involved and the various ways in which values are expressed and readers are allied." Evaluation resources are divided into three categories according to the objects of evaluation: the evaluation of the value of things (identification), the evaluation of people's character and behavior (evaluation), and the expression of people's emotions (emotion). At the same time, it can also be investigated from two dimensions of classification and sound source.

In China, Wang (2012) further elaborated the evaluation theory. He believed that the evaluation theory could be used as an analytical tool to find the deep meaning behind the surface words. Therefore, it is feasible to use evaluation theory to analyze discourse. Evaluation theory consists of three systems: attitude system, intervention system, and range system (Fei \& University, 2014). Attitude systems are divided into emotion, judgment, and appreciation. The intervention system is divided into self-speech and borrowing. The range system is divided into linguistic potential and focusing. Among them, the attitude system is the most critical and has two sides. Emotion is the most important subsystem of the attitude system, which refers to the speaker's attitude towards the described object. The judgment system belongs to the ethical category and evaluates the behavior of language users according to ethical and moral standards. Its positive evaluation has the meaning of appreciation, while the negative one has the meaning of condemnation. The appreciation system belongs to the category of aesthetics, which refers to the evaluation of a text, process, and phenomenon.

\section{Comparisons of News Reports of China Daily and Time}

\section{Data Collection}

This paper selected the reports related to COVID-19 from China Daily and Time from January 7, 2020, to February 1, 2021, for comparative analysis. Among them, 11 articles were selected for an excerpt. There are 1,915 words from China Daily and 4,634 words from Time in these news articles. The detail of news references is given in Appendix A.

Analysis of China Daily: After the outbreak of the COVID-19 in China, the Chinese people are united as one and full of confidence in overcoming the COVID-19. This is inseparable from the news media, the most important of which is transparency and timeliness. 
Taking reports from January 29 to February 3 as examples, these 6 days were in the outbreak period. A total of 314 news articles were posted on the China Daily website, an average of 52 a day. The content covers the development of the event and related reports (23\%), supervision, management and prevention and control (26\%), post-occurrence measures (22\%), event-related knowledge and prevention and control science (5\%), assistance from various parties (8\%), international voice (9\%), economy (4\%) and others (3\%) (Fig. 1). It not only updates English news frequently but also covers all aspects and delivers the most full and comprehensive information to the international community openly and transparently.

For the media, the first important element in responding to a public health crisis such as COVID-19 should be transparency. Regester (1993), a famous British expert on Crisis Management, said in his book Crisis Management, timely, active, full, and repeated information are the basic principles and main strategies of the news release in response to crises. A previous study that looked at the relationship between the amount of media coverage and the amount of disease spread found that a tenfold increase in media coverage was associated with a 33.5 percent decrease in the number of such infections (Shih et al., 2008). Therefore, media may be an effective means of preventing the spread of disease.

According to the data mentioned above, China's progress of the COVID-19, prevention and control work, response measures, and knowledge popularization has been reported transparently both at home and abroad. According to a report on the U.S. Newsweek website on February 3, the importance Chinese officials attach to the epidemic and the transparency of news sharing has been recognized by the Western media.

Analysis of Time: Time published a total of 1811 articles related to the COVID-19 in China. Since February 26, 2020, the number of new cases of COVID-19 outside China has been more than inside China every day. Time shifted its focus to the world and the number of reports on COVID-19 related to China began to decline. In early March 2020, the COVID-19 outbreak began to spread around the world. Time gradually decreased and the focus of the coverage shifted to the United States. It can be seen that Time has shown great concern about the COVID-19 epidemic in China. At the same time, we have made timely, uninterrupted, and multi-faceted reports on the development of the epidemic in China and its impact, to seize the opportunity to set the agenda. The fluctuation of the number of reports is influenced by the severity of the epidemic
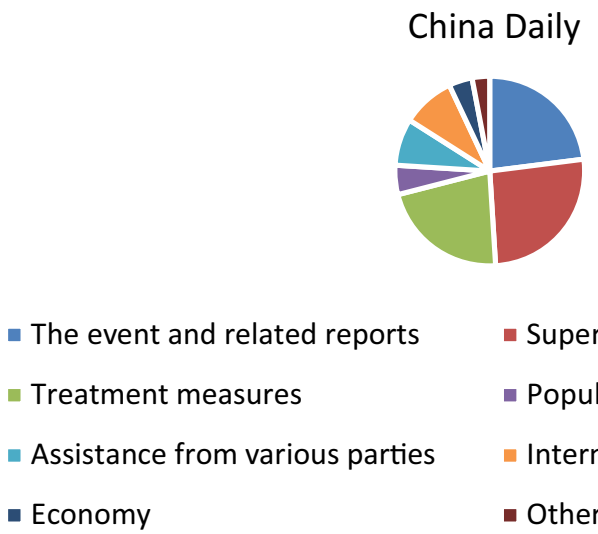
- Supervision and control
- Popularizing prevention knowledge
- International voice
- Others

Fig. 1 Content distribution map of China Daily 
and important events. Several subject words can be obtained from them. The top 100 subject words are selected according to the order of topicality. After eliminating some functional words, the focus of the Times' report on COVID-19 in China can be roughly divided into the following aspects:

Each media has its perspective and choice in reporting the event and forms different topics and positions in reporting the event. The analysis of the subject words can further confirm and judge the choice and bias of the media in reporting this event. As shown in Table 1, the classification of subject words shows that Time covered the COVID19 epidemic in China around topics such as virus, characteristics, the progress of the epidemic, prevention and control measures, impact, time, place, and people. From the above data, it is not difficult to find that Time reports on China focus on two topics: the COVID-19 epidemic itself, involving the virus and its characteristics, the progress and prevention and control of the epidemic with each topic accounting for $35 \%$ of the total. The use of the words "Coronavirus, Deaths, Respiratory, Death, Death, Outbreak, Quarantine, Lockdown, Restrictions, Epicenter" suggests that novel coronavirus is more transmissible than SARS and can cause more deaths. For example The main symptoms are upper respiratory symptoms. Wuhan is the epicenter of COVID-19 in China. The COVID-19 outbreak started in Wuhan and spread to other areas. Quarantine and city closure are the main measures taken by the Chinese government to prevent and control the epidemic.

One of the highlights of the Time report is factual information on the real-time development of COVID-19 in China. Readers seem to feel that their reports are objective and respectful of the facts. However, as the mainstream western media, their reports on the COVID-19 almost have no positive words. They do not introduce China's efforts and achievements in combating COVID-19 in detail and do not highlight the image of China's initiative. The Chinese government has imposed restrictions on traffic, closed schools, strict quarantines, and forced isolation. The goal is to prevent millions of people from becoming infected with COVID-19 and to protect the safety and health of the general public. Time couldn't care less about how the Chinese government mobilized its people to fight the epidemic. It also ignores China's determination to sacrifice its own economy to protect the health of the world's people. The reports ignored the dedication of the brave Chinese doctors, nurses, and ordinary citizens who have battled the virus to their death. On the contrary, political themes like "official, government, authorities, communist" suggest that the NYT is not worried about how many lives the disease will take. Instead, the NYT is doing economic calculations as well as political calculations and the crisis caused by COVID-19 which gives them an excuse to comment on China.

In order to observe Time's attitude towards the Chinese government's prevention and control efforts, it can be seen that the author uses the high-frequency subject word "government" to further analyze the relationship between "government" and its collocation words. We find that most of them are "dissatisfaction, withheld, mishandled, question, complaints, corruption, misstep, blamed, accuse, struggle, and petition". The negative meaning of these words is more prominent. On the whole, Time's report reflects its relatively negative attitude towards the Chinese government. 


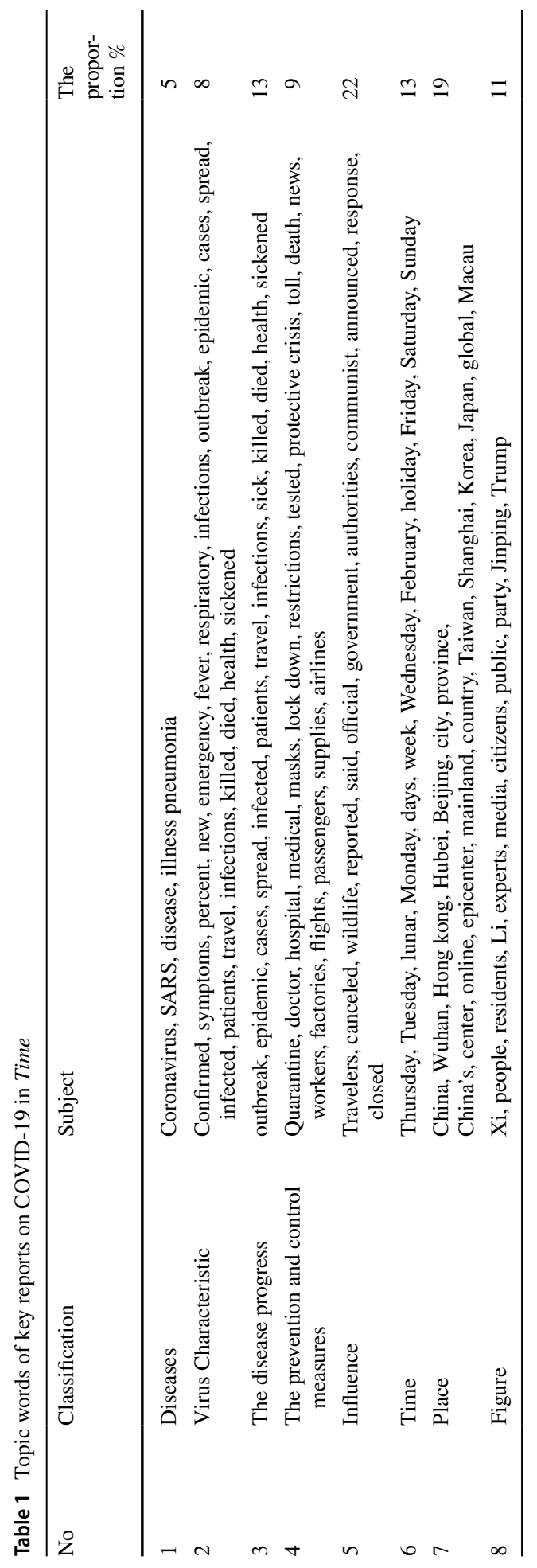




\section{Comparison of the Words Used in News Reports}

After the occurrence of public health emergencies, the media should report them rationally and objectively. The media plays a very important role in how to objectively report the epidemic, reduce public panic and maintain social stability.

Just as Kurt Lewin, an American social psychologist and one of the four pioneers of communication, believes that information is always controlled by a pair of invisible hands in the process of transmission, which is gatekeepers. In the news release of the event, besides the government, the media plays a very important role as gatekeepers (Lewin, 1947). In terms of collection and editing, the gatekeeper should first be objective and neutral, which is also reflected in the words used in news reports.

After searching the Time's reports about the COVID-19 from January 6 to February 3 , we analyzed the keywords. In reporting the progress of the epidemic, the paper used many keywords including "spike", "exponentially" and "enormous". By comparison, the keywords used by China Daily, such as "increase", "climb to", "bring the number to" and "total" are more objective and neutral. In English, the word "exponentially" has been coined to describe the number of cases that have been confirmed. China Daily's standard use of words can help people rationally and correctly view the progress of the event. The authors found that Time exaggerated the danger of the virus and the consequences of its spread. For example, Time uses the word "spread" more than 200 times to describe the spread of a virus or panic. On average, there are nearly four mentions per story and most of them are used as a verb. Like another popular phrase, "pass around," "spread" here focuses on a virus "spreading around," which tends to create negative impressions and panic.

In contrast, China Daily's extensive use of the word "spread" appears almost exclusively as a noun. Instead, they are often accompanied by "curb", "control" and "contain" to signal the government's efforts to curb the spread of the disease. China Daily has spread throughout the country and among Chinese people throughout the country. In addition, Time wrote that the COVID-19 infection pneumonia is a "global pandemic." A pandemic is a large one with a large number of deaths. It can even affect infectious diseases on many continents around the world.

In European history, there were two famous pandemics: the Spanish flu in the early twentieth century and the bubonic plague in the mid-fourteenth century (Sun 27). However, the COVID-19 did not reach this level and was quickly controlled after the outbreak. Time used the word "struggle" while China Daily used the word "fight" to describe how the Chinese government is fighting the epidemic. In contrast to "fight", "struggle" is a word that means you are powerless and struggling. While Time frequently used the word "control" to describe the outbreak, China Daily used "curb" to give its readers a more determined response. Second, Time frequently uses "rapidly" when talking about accelerating the development of drugs and vaccines. The word "accelerate" used by China Daily is a sign that the Chinese government is rapidly accelerating its efforts to develop rapidly.

Meanwhile, Time looks at the social, economic, and political impact of the COVID19 outbreak. In many articles, words such as "crisis, workers, factories, flights, passengers, supplies, travelers, departing" frequently appear. For example, with the further spread of COVID-19 and the continuous upgrading of epidemic prevention and control measures, many of the country's enterprises and factories have been shut down. Some flights have been canceled and the normal operation of society has been greatly affected. In the context of globalization, the damage caused by the epidemic to the domestic economy and financial market will inevitably spread to all countries in the world. 


\section{Comparative Analysis of Attitude Systems}

\section{Judgment System}

The evaluation system uses different criteria to judge the good or bad behavior of language users. Social constraints are mainly divided based on the authenticity and reliability of the behavior. A positive review implies praise, while a negative review implies condemnation. Among the eight reports, China Daily used 38 judgment words, accounting for $37.2 \%$, including $28.4 \%$ positive comments and $8.8 \%$ negative comments. Time used 102 judgment words, accounting for $43.9 \%$, of which $23.7 \%$ were positive and $20.2 \%$ were negative. Both Chinese and American media have used a lot of systematic words. The positive comments on the Chinese side far outnumber the negative ones, while the difference between the US side and the Chinese side is small.

Example 1: IMF chief Kristalina Georgieva said on Friday while viewing the role of China's economy in saving the global economy from recession amid coronavirus pandemic (Georgieva).

Example 2: Beijing is also committed to continuing to provide "as much assistance as it can" to Iran to curb the outbreak (Hassan).

In Example 1, China Daily uses the two judgment words "saving" and "recession." The former is positive and the latter is negative. It is intended to convey that the global economy has been affected by COVID-19, but China is trying to rescue the slumping world economy. The whole clause expresses our praise to China.

In Example 2, "can", "curb" and "as much as" were used to express China's willingness to do its utmost to help Iran combat the epidemic.

Example 3: Still, China's official press agency Xinhua has already announced a forthcoming book on how Xi's "outstanding leadership as a great power leader" defeated the virus (KEN MORITSUGU and AP).

In example 3, American media uses "Outstanding, Great Power and defeated". The intervention system shows that the outstanding leadership of Chinese leaders is part of the reason for the victory over the epidemic, which is consistent with the truth. Since the outbreak of COVID-19, General Secretary Xi has personally deployed and directed the fight against the epidemic. At the same time, the people of the whole country are working with one heart and one mind to win the battle against the epidemic.

\section{Affective System}

In news discourse, in order to make the report appear objective and fair, language users will try to reduce the use of emotional words. The affective system has three sets of variables, happy (unhappy), safe (insecure) and satisfied (dissatisfied). The frequency of the emotion system used by Chinese media was $11.8 \%$, including $6.9 \%$ positive comments and $4.9 \%$ negative comments. The frequency of the emotional system used by the American media was $24.6 \%$, including $5.6 \%$ positive comments and $19 \%$ negative comments. There is a big difference in the use of emotional resources between the two countries. Chinese media use fewer emotional words, while American media use more emotional words and more negative evaluation words.

Example 4: As cases of COVID-19 stabilize in China and soar across the U.S., Middle East, and Europe, the Beijing government has been busy recasting China as a sanctuary 
from the deadly virus, which has so far sickened 169,000 and killed at least 7000 across the world. (CAMPBELL)

Example 5:Another comment appended to the profile of a whistleblower doctor quickly went viral:" The doctor risks her job to take the interview, the reporter risks being charged with fabricating rumors to write the article, the media risks being shut down to publish the article, and people on WeChat risk having their accounts blocked to share the article. Today we need this ridiculous level of tacit cooperation just for a word of truth." (CAMPBELL)

In example 4, the words 'stabilize' and 'sanctuary' both mean' security. It shows that the epidemic in China has been basically under control. The words 'Deadly', 'Sickened' and 'killed' all indicate insecurity and emphasize that the epidemic is highly contagious and spreads widely.

In Example 5, the use of four "risks" indicates insecurity, indicating that doctors, journalists, media and the general public in China are all playing a role in disseminating the true situation of the epidemic in China. It also reflects the openness and transparency of the Chinese government in releasing information about the epidemic.

Example 6: LOS ANGELES - Los Angeles Mayor Eric Garcetti expressed his gratitude Thursday to the Chinese cities of Shanghai and Guangzhou for helping the second largest city of the United States fight COVID-19 (Garcetti).

In Example 6, the word "gratitude" means happiness. The mayor of LosAngeles thanked the Chinese cities of Shanghai and Guangzhou for helping Los Angeles fight the epidemic. The actions of the Chinese government and people have proved to the world that the building of a community with a shared future for mankind is not an empty promise but an objective fact. At the same time, the interventional system is used to make the report more objective and real.

\section{Appreciation System}

The system of appreciation consists of three parts: how we react to things, what they are made of and what they are worth. Chinese media used 18 words, accounting for $17.6 \%$ of the three systems. American media use five words, accounting for about $2.1 \%$ of the three systems. The media of the two countries differ greatly in the use of appreciative words.

Example 7: China hopes to benefit from a realization in the West of how difficult it is to bring the virus under control, said Julian $\mathrm{Ku}$, a law professor at Hofstra University in New York $(\mathrm{Ku})$.

Example 8: Garcetti also said that global cooperation is an important way to cope with the pandemic (Garcetti).

In example 7, the word "difficult" indicates that COVID-19 is dangerous and highly contagious. Moreover, there is no magic bullet. In example 8, "cooperation" and "important" indicate that the fight against the COVID-19 is not a matter of one country and no country can stay aloof from its efforts. Only by working hand in hand and making concerted efforts can we win the fight against the COVID-19.

\section{Intervention System}

Texts are conversational and journalistic texts are also conversational. Journalists can express their own views and attitudes and have a dialogue with readers by intervening in others' words in their reports. In these eight reports, China Daily used interventional words for 34 times and Time for 68 times, accounting for $33.3 \%$ and $29.3 \%$ 
respectively. There is not much difference in frequency. It can be concluded that both Chinese and American media use a large number of external voices to indirectly express their attitudes and try their best to leave an objective impression on readers.

Example 9: "China doing better in 2020, is very important for China. It is also very important for the rest of the world given China's share in the world economy," the IMF chief emphasized. (IMF)

Example 10: China has made a "promising start to rebooting its economy" and controlling the spread of COVID-19, according to a report from Imperial College London, providing hope for nations in lockdown due to the pandemic (McNEICE).

Example 11: "I want to thank Shanghai and our sister city Guangzhou, who are sending medical masks and widely needed personal protective equipment for our front line doctors and nurses and medical teams," Garcetti said." This is the power of partnerships This is how we tap into our relationships in order to protect our people." (Garcetti)

In Examples 9, 10, and 11, China Daily has directly introduced the discourse of authoritative figures. The use of words such as "important", "promising" and "rebooting" shows that China's economy, despite the impact of the COVID-19 epidemic is still on a good momentum of development and will contribute to the recovery of the world economy. Example 11 directly quotes the statement of the mayor of Los Angeles. On one hand, it shows the severity of the epidemic in the United States. On the other hand, it shows that China is practicing a community with a shared future for mankind, practicing the humanitarian spirit and helping other countries overcome the epidemic at an early date. This is what China is trying to do.

Example 12: "I'm trying to stay active and positive," says Lee,27, a business manager for Shanghai-based media platform Radii. "I've been doing push-ups and trying to do all the reading and writing that I haven't had Time for." (Lee)

Example 13: China hopes to benefit from a realization in the West of how difficult it is to bring the virus under control, said Julian $\mathrm{Ku}$, a law professor at Hofstra University in New York. (Ku)

Example 14: Dr. Tedros Adhanom Ghebreyesus, the W.H.O.'s director general, said that the measures put in place in Hubei appear to be "paying off," but he cautioned that outbreaks can be unpredictable. "We have to understand it with caution because it can show stability for a few days and then they can shoot up, "he said. "I've said it many Times: It's slow now, but it may accelerate, "he said, according to the New York Times (Ghebreyesus).

In example 12, Time quoted the words of the Chinese manager aiming to convince the readers that the life of Chinese people has not returned to normal and the work and life are still greatly affected. In example 13, China wants to reshape its voice in the world. China has always been a country where kindness is rewarded. China has also done its best to return protective materials to its friends, sending teams of experts to exchange experience with them. At the same time, we will also donate protective materials to countries severely affected by the epidemic or economically backward. China has donated US \$20 million to the World Health Organization (WHO) for the fight against COVID-19, thus staying true to original aspiration with concrete actions. Example 14 fully shows that China has achieved results in fighting the epidemic, but there are still risks. Low risk does not mean zero risks. The Chinese government and people need to continue to take precautions so that low risk will become zero risks at an early date. 


\section{Cause Analysis}

The cultural, value, and ideological differences between China and the United States determine that the Chinese and American media have different reporting perspectives and characteristics in reporting events. The analysis of the characteristics of the Chinese and American media in reporting disaster news can more directly reveal the specific differences between the Chinese and American media in reporting disaster news.

\section{Cultural Reasons}

Since ancient times, China has attached great importance to the role of human subjective initiative. The idea of "unity of man and nature" shows that China attaches great importance to the stable and coordinated development of things and holds the view that all things in the world can coexist peacefully (Zou, 2008). In traditional Chinese culture, it emphasizes the value orientation centered on collectivism and advocates the disregard of personal gains and losses. The interests of the society and the state are above the interests of the individual. Therefore, in the disaster news, the news speech should take social stability as the premise. Focusing on the overall cultural background, China's disaster news puts more emphasis on "group picture" reports, such as rescue teams and governments at all levels, and expresses relatively few individual voices.

American media emphasizes the value of the individual (Lin, 2001), based on the perspective of the victim. Therefore, in the news reporting of disaster events, it is often based on the individual victims. At the same time, the American media takes the individuals suffering from the disaster as the main body of the disaster news report, and describes the disaster from the perspective of the individuals. In addition, when American media collect and write news articles about disasters, they often introduce the specific victims and forms of disasters, such as the collapse of houses, to launch disaster reports.

\section{Social Reasons}

China's journalism was born at the time of national survival, which determines the contents and methods of disaster news reports are more inclined to social stability, adhering to the concept of "positive publicity first" and maintaining the national image and overall stability. Due to the influence of social factors on Chinese media, the disaster news reports in China are significantly different from those in the West in terms of information release and content. China's social system determines that news reports in China value the state more than the individual. Therefore, Chinese media focuses more on the whole when reporting social news. The Chinese businesses also reflect corporate social responsibility and corporate volunteering (Farooq et al., 2020). They mainly focus on the groups in the disaster and mainly reflect the emergency measures taken by the state, the government and the society in all aspects giving an extended expression of social responsibility.

However, in western capitalist countries, news media is produced by economic competition and is a relatively independent economic entity. The government's control over news media is weak and the freedom of news is relatively high. However, when media reports touch national interests and security, the government will make full use of the corresponding power to exert the function of controlling news. The American news report is a humancentered value, emphasizing personal interests, which makes the American media choose a person as the main body when reporting disaster news. The report focuses on the lives 
of individuals and personal heroes in disasters. The US media likes to report their living conditions and the environment from the perspective of individuals. It always focuses on the harm and destruction caused to people by the epidemic and directly presenting the suffering and misery of people.

Because of the ideological differences between the two countries, contradictions and conflicts continue. The problem of the source of novel coronavirus is scientific problem, so we need to listen to professional and scientific opinions. Viruses have nothing to do with borders, race or wealth. It is the common enemy of mankind, and no country can stay aloof from it. The Chinese people have made great sacrifices and significant contributions to safeguarding global public health and human health and security. As a result, China has been fully recognized, highly appraised and widely praised by the international community. On the contrary, Time puts on ideological colored glasses, trying to stigmatize China's fight against the epidemic and try to shift responsibility to China. This approach ignores the enormous contribution of the Chinese people to safeguarding human health and safety. The US media's attempt to smear China's important contribution to global public health security runs counter to the view of the international community to jointly fight the epidemic.

\section{Differences in Media Styles}

\section{Different Reporting Styles of Media}

China's journalism has a long history of politicians running newspapers. The Chinese media has been called the tongue of the Party and the people, representing both the views of the government and the interests of the vast majority of the people. Therefore, disaster events are mostly reported from the perspective of the government and the people.

American media pay attention to the strong stimulation of the audience's senses and the strength of the content to attract the audience, so they pursue the interest and stimulation of the content in the report of disaster news (Downing, 2003). In order to leave a deep impression in the hearts of the audience, they often insert powerful photos of the scene into the reports to improve the popularity of their own media and expand their influence. This is because American newspapers are mainly run by entrepreneurs, who are more concerned with economic benefits. So, almost all media are private companies in USA. As commercial media, according to the commercial operation mechanism, driven by the market economy, the maximum profit has become their highest goal. To this end, journalists need to keep an eye on the needs of the audience. Sometimes they pander to their readers in order to increase their ratings and circulation and to boost their finances.

\section{Different Purposes of Reporting}

Chinese media coverage has focused on resolving the tragedy. The report of disaster news often adopts a cautious attitude and focuses more on the positive spirit of people in the COVID-19 prevention and control, such as the report of how the relevant departments fight the disaster and provide relief. China's coverage of the epidemic has focused on dispelling the tragic nature of the COVID-19 to stabilize people's minds and boost morale. Unlike the American media, the Chinese media focused on the decision-making of leading cadres, the popularization of scientific knowledge and the optimism of people from all over the 
country united in fighting the epidemic. In order to eliminate the spread of the epidemic brought about by people's fear and anxiety.

Second, only to national events and war news, disaster news is one of the most concerned news by the American media. Conflict and unusual are indispensable elements in the news value of the United States. Therefore, the conflict between man and nature, such as the disaster itself and the tragic situation of victims becomes the focus of the disaster report. The American media focuses on the disaster itself and face the tragedy caused by the disaster when reporting the disaster. The American journalists painted the facts in a large number of strokes, focusing on the devastation of the disaster and the misery and helplessness of the victims. No matter the length of the report, or the technique and intensity of the report, it can be seen that the American media's reports on disaster news focus on the disaster itself.

\section{Conclusive Discussion}

\section{Findings in the Study}

The news report is not as objective as it should be. Readers' views on events are often influenced by the media. It is appropriate to say that the COVID-19 is a test. The COVID-19 has tested many aspects of the country, including the news media. Tuchman, an American sociologist, believes that mass media have constituted many fine-grained news networks for modern society. It is not just about spatially determining where the news is, it is also about what kind of world we see. That is to say, each piece of news, what it chooses in reality, what position it makes them in a news text and how to explain them will affect people's understanding and judgment of the outside world. The same is true if you apply this theory to the coverage of the COVID-19.

The Chinese government and media responded quickly to the COVID-19 with adequate psychology by expressing social responsibility to the world, and the Chinese people followed suit in fighting the epidemic comprehensively. The rapid control of the epidemic in China is not only due to the correct and prompt measures taken by the government but also due to the contributions of the media.

There is so much rumor and panic in the US and the media is the major cause. The COVID-19 outbreak in early 2020 neither boosted bilateral cooperation in the field of public health nor delayed the downward trend in bilateral relations. The outbreak and its response have been a catalyst for further deterioration of bilateral relations. The US prefers a confrontational approach to bilateral differences and treats all issues as a matter of national security. The public opinion war centered on the source of novel coronavirus poisons the atmosphere of bilateral relations, which is more helpful for the hardliners in the Trump administration to construct the image of "strategic competitor" and shape the "China threat". The effectiveness of China and the United States in fighting the epidemic is significantly different in their own countries and their performance in the international arena is also very different. China has provided anti-epidemic assistance to many countries, while the United States has not only failed to assist other countries but also refused to coordinate and cooperate with major countries. Therefore, the game between China and the United States at the international level has a sense of competition between system and order. The differences and contradictions between China and the United States are becoming more comprehensive, security-oriented and ideologically oriented and even face the 
risk of slipping into strategic confrontation. Based on the basic reality of China-US relations, we should focus on "cutting losses" and "maintaining stability". This is the way to manage bilateral relations in the future.

The main reason why the US media used negative coverage on this issue is that the US is afraid of the development trend of China. China has risen from a backwater to the world's second-largest economy in just a few decades and it is accelerating to catch up in technology, military and other fields. The rise of China poses a threat to the interests of western countries, so the voice of western media to suppress China's development is increasing. The news media of a country must carry out news reporting activities based on its national interests. In order to achieve the purpose of containing China, the United States suppressed China in all aspects. In addition, the US media has also denigrated China for using the virus crisis to position itself as a global leader and to expand indefinitely the impact of the virus on the world.

\section{Suggestions for Reporters and Readers}

Language is not only a tool of communication and thinking but also intervention and influence on social development. Especially in front of the public, language invisibly pushes others to see the world in a certain way.

Although Time has shown great concern about the COVID-19 epidemic in China, it has also carried out timely, uninterrupted, and multi-faceted reports. However, they still hold misunderstanding, prejudice, and negative attitude towards the Chinese government and make groundless accusations against the Chinese government. Western media's reports on China are generally influenced by their countries' basic stance towards China and their deep-rooted ideology and prejudice. Due to their different stances and tendencies, the Western media often distort China's image and even deliberately belittle China. Different national interests and stances will inevitably affect the news reports of a country's media. Some of the reports by Time distorted China's efforts and results in fighting the epidemic, which to some extent raised doubts on China by the international community. The American media and politicians have always believed that their own system is the best in the world and have a habit of labeling others as "undemocratic" for systems that are different from their own. When China made great achievements in its socialist democracy, many American media held high the banner of political correctness and distorted the truth.

It can be seen that critical discourse analysis plays a role in revealing secrets. This paper makes a systematic analysis of the theme, words and attitude of the news reports of the same event in the same period of time. The authors find that although the newspapers try to pursue objectivity, the Chinese newspapers implicitly have a positive attitude towards the recovery of the epidemic and are in line with the purpose of maintaining social stability and people's safety. Times mainly stands on the US side, showing its misunderstanding and negative attitude towards the Chinese government and making groundless accusations against the Chinese government. The novel virus is carefully associated with China by them. It obstructs China's cooperation with other countries and maliciously interprets China's aid to other countries. Therefore, as a report of social events, it can be said that no report is completely neutral. Readers should be more sensitive to the ideological and psychological meaning reflected in the language and think more critically when interpreting the news text.

The battle of public opinion between China and the Western media is likely to persist for a long time. Therefore, readers should continue to enhance their psychological 
comprehensive power, in particular, continue to improve the capacity and level of international communication and promote positive things to reduce the panic.

\section{Appendix A}

\section{Detail of News References}

ANGUS McNEICE.China's gains offer hope for the world[N/OL].China Daily, 2020[202004-29].http://www.chinadaily.com.cn/a/202003/28/WS5e7ebab7a310128217282afa.html.

BLOOMBERG FEBRUARY.Doctors in China Are Starting Human Trials for a CoronaviruTreatment[N/OL].Time,2020[2020-04-29].https://www.cbsnews.com/ liveupdates/coronavirus-death-toll-infections-outbreak-evacuations-cruise-ship-latestupdates-2020-02-11/.

CGTN. IMF: China offers tremendous experience to the world against COVID-19[N/ OL].ChinaDaily,2020[2020-04-29].http://www.chinadaily.com.cn/a/202003/29/WS5e7 fee08a310128217282bff.html.

CHARLIE CAMPBELL\& SHANGHAI.Life in China Has Not Returned to Normal, Despite What the Government Says[N/OL].Time,2020[2020-04-29].https:// www.teleg raph.co.uk/news/2020/01/24/coronavirus-fears-rise-chinese-cover-up-40-million-lockd own/.

Freudenburg, W. R., Coleman, C. L., Gonzales, J., \& Helgeland, C. (1996). Media coverage of hazard events: Analyzing the assumptions. Risk analysis, 16(1), 31-42.

Jonathan Arnott.Medical necessity or irrational fear.China Daily,2020[2020-04-29]. http://www.chinadaily.com.cn/a/202002/03/WS5e37865ba310128217274570.html.

KEN MORITSUGU\&AP.China Sends Masks, Gloves and Test Kits to Nations Affected by COVID-19 [N/OL].Time,2020[2020-04-29].http://www.xinhuanet. com/english/ 202101/15/c_139670094.htm.

Md Enamul Hassan.China emerges as a'friend of humanity'[N/OL].China Daily, 2020[2020-04-29].http://eng.chinamil.com.cn/view/2020-04/03/content_9784319.htm.

Wodak, R, and Meyer, M. Methods of Critical Discourse Analysis. London: SAGE Publications, 2001.

Xinhua. Los Angeles mayor appreciates Chinese cities' help in fighting COVID-19 [N/OL].China Daily,2020[2020-04-29].http://www.xinhuanet.com/english/2020-03/ 27/c_138923119.htm.

\section{Declarations}

Conflict of interest Authors declare that there is no conflict of interest.

Ethical Approval Approval was accorded by the ethical committee on linguistic research formed by the first author in Shanghai.

\section{References}

Downing, J. D. (2003). Audiences and readers of alternative media: The absent lure of the virtually unknown. Media, Culture \& Society, 25(5), 625-645. 
Eggins, S. (2004). Introduction to systemic functional linguistics. A\&C Black.

Essam, B. A., \& Abdo, M. S. (2020). How do arab tweeters perceive the covid-19 pandemic? Journal of Psycholinguistic Research, 50, 507-521.

Farooq, Q., Liu, X., Fu, P., \& Hao, Y. (2020). Volunteering sustainability: An advancement in corporate social responsibility conceptualization. Corporate Social Responsibility and Environmental Management. https://doi.org/10.1002/csr.1893

Fei, W., \& University, H.E. (2014). Analysis of evaluation theory perspective attitude speech discourse resources-take rogge' speech in 2012 london olympics for example. Journal of Jiamusi Vocational Institute.

Halliday, M. A. K., \& Matthiessen, C. M. (2013). Halliday's introduction to functional grammar. Routledge.

Lewin, K. (1947). Frontiers in group dynamics: Ii. Channels of group life; social planning and action research. Human Relations, 1(2), 143-153.

Lin, C. A. (2001). Cultural values reflected in chinese and american television advertising. Journal of Advertising, 30(4), 83-94.

Martin, J. R., \& White, P. R. (2003). The language of evaluation (Vol. 2). Springer.

Regester, M. (1993). Crisis management Financial public relations (pp. 100-109): Elsevier.

Romaine, S. (2000). Language in society: An introduction to sociolinguistics. Oxford University Press.

Shih, T.-J., Wijaya, R., \& Brossard, D. (2008). Media coverage of public health epidemics: Linking framing and issue attention cycle toward an integrated theory of print news coverage of epidemics. Mass Communication \& Society, 11(2), 141-160.

Wang, Z. (2012). James r.Martin's studies of legal language and their inspirations. Contemporary Foreign Languages Studies.

Wodak, R., \& Meyer, M. (2015). Methods of critical discourse studies. Sage.

Zou, L. (2008). Development-oriented finance and economy in china: A historical review and prognostic assesment: AuthorHouse.

Publisher's Note Springer Nature remains neutral with regard to jurisdictional claims in published maps and institutional affiliations.

\section{Authors and Affiliations}

\section{Yanni Zhang ${ }^{1} \cdot$ Naveed Akhtar $^{3} \cdot$ Qamar Farooq $^{2,3} \cdot$ Yiwei Yuan $^{4} \cdot$ Irfan Ullah Khan $^{5}$}

1 School of Foreign Languages, Shanghai Lixin University of Accounting and Finance, Shanghai, China

2 College of Economics and Management, Zhejiang Normal University, Jinhua, China

3 Faculty of Management Sciences, National University of Modern Languages, Islamabad, Pakistan

4 No.2 Zhujing Primary School Jinshan District, Shanghai, China

5 Center for Non-Traditional and Peaceful Development Studies, School of Public Affairs, Zhejiang University, Hangzhou, China 